\title{
Ketidakpastian dan Penggunaan Utang Perusahaan
}

\author{
Rita Juliana \\ Universitas Pelita Harapan \\ rita.juliana@uph.edu
}

\begin{abstract}
Uncertainty has been discussed as the core element of the slow economic recovery during the global financial crisis 2008-2009. The goal of this paper is specifically aiming to observe the effect of uncertainty to the firm's financing policy. In this research, we utilize uncertainty in Indonesia level and world level that are developed by Ahir et al. (2018). The sample of this study are Indonesian companies that are listed in Indonesian Stock Exchange (IDX) from period 2007 until 2019. The methodology we used was panel data regression. The result of this study show that uncertainty decrease the firm's leverage level. This situation is caused by uncertainty that increase firm's manager concern about their long-term solvency.
\end{abstract}

Keywords: Uncertainty, Leverage, Debt, Panel Data Regression

\begin{abstract}
Abstrak
Ketidakpastian didiskusikan menjadi elemen utama dari lambatnya pemulihan ekonomi setelah krisis keuangan global tahun 2008-2009. Penelitian ini secara spesifik ingin mengobservasi efek dari ketidakpastian pada kebijakan pendanaan perusahaan. Pada penelitian ini, kami menggunakan ukuran ketidakpastian pada level Indonesia dan dunia yang dikembangkan oleh Ahir et al. (2018). Sampel penelitian ini adalah perusahaan yang terdaftar pada Bursa Efek Indonesia pada periode 2007 hingga 2019. Metode yang digunakan adalah regresi model panel data. Hasil dari penelitian ini menunjukkan bahwa ketidakpastian menurunkan tingkat utang yang digunakan perusahaan. Hal ini dapat disebabkan karena ketidakpastian meningkatkan kekhawatiran manajer perusahaan mengenai solvabilitas jangka panjang perusahaan.
\end{abstract}

Kata Kunci: Ketidakpastian, Tingkat Utang, Regresi Panel Data 


\section{PENDAHULUAN}

Ketidakpastian menjadi kekhawatiran bagi banyak aktor di ekonomi, seperti pemerintah dan perusahaan. Perusahaan akan lebih mudah melakukan perencanaan dan melakukan pengambilan keputusan jika informasi yang mengenai masa depan dapat diobservasi secara jelas. Menurut Stokey (2016), ketidakpastian menyebabkan perusahaan untuk melakukan "wait and see" menunda investasi untuk mendapatkan informasi yang lebih jelas. Hal ini memberikan dampak pada level makro, ketidakpastian dapat mempengaruhi perekonomian melalui pengurangan pada investasi, output, dan lapangan kerja (Baker et al., 2016).

Ketidakpastian menyebabkan perusahaan untuk mengurangi jumlah investasi (Gulen dan Ion, 2016) dan inovasi (Xu, 2020) mereka, salah satunya dikarenakan oleh friksi keuangan. Di saat tingginya ketidakpastian, informasi yang ada di ekonomi menjadi tidak jelas dan menyebabkan perbedaan pendapat antar aktor ekonomi (Lee et al., 2019). Informasi asimetris yang tinggi juga terjadi pada pihak internal (manajer) dan eksternal perusahaan (investor dan kreditor). Investor dan kreditor menarik keputusan untuk berinvestasi dan menyebabkan jumlah pendanaan yang tersedia menjadi terbatas. Ketidakpastian terjadi karena perubahan kebijakan ekonomi mempengaruhi aktivitas operasional perusahaan sehingga menyebabkan peningkatan volatilitas arus kas perusahaan yang menyebabkan fluktuasi perubahan harga aset perusahaan (Pástor dan Veronesi, 2013) dan meningkatnya kemungkinan gagal bayar perusahaan (Francis et al., 2014).

Menurut Xu (2020), ketidakpastian meningkatkan friksi keuangan dan menyebabkan biaya pendanaan eksternal yang mahal. Dengan meningkatnya kemungkinan gagal bayar perusahaan menyebabkan investor dan kreditor untuk menuntut tingkat pengembalian (yield spread) yang lebih tinggi. Hal yang didukung dengan hasil yang juga ditemukan oleh Waisman et al. (2015) yaitu bahwa ketidakpastian politik meningkatkan biaya utang perusahaan. Sehingga, biaya pendanaan eksternal yang mahal membuat perusahaan untuk mengalami kesulitan untuk mendanai investasi akan kesempatan pertumbuhan yang dimiliki perusahaan.

Mahalnya biaya utang yang dikenakan kreditor membatasi kemampuan perusahaan untuk mengambil utang (Cao et al., 2017). Ketidakpastian membuat perusahaan untuk bersikap risk adverse. Kekhawatiran akan kemampuan untuk membayar kewajiban menurun menyebabkan perusahaan untuk menghindari masuk ke dalam kontrak utang. Untuk meningkatkan kemampuan survival atas resesi ekonomi, perusahaan memilih untuk meningkatkan fleksibilitas finansialnya. Cao et al. (2017) dan Phan, et al. (2019) menemukan bahwa pada saat ketidakpastian tinggi, perusahaan cenderung memilih untuk meningkatkan cash holding perusahaan. Hal ini juga membuat perusahaan menyesuaikan struktur modalnya dengan menurunkan tingkat utang yang dimilikinya. Berikut ini ditampilkan grafik Indeks Ketidakpastian Dunia periode 2007-2019: 
Grafik 1. World Uncertainty Index period 2007-2019

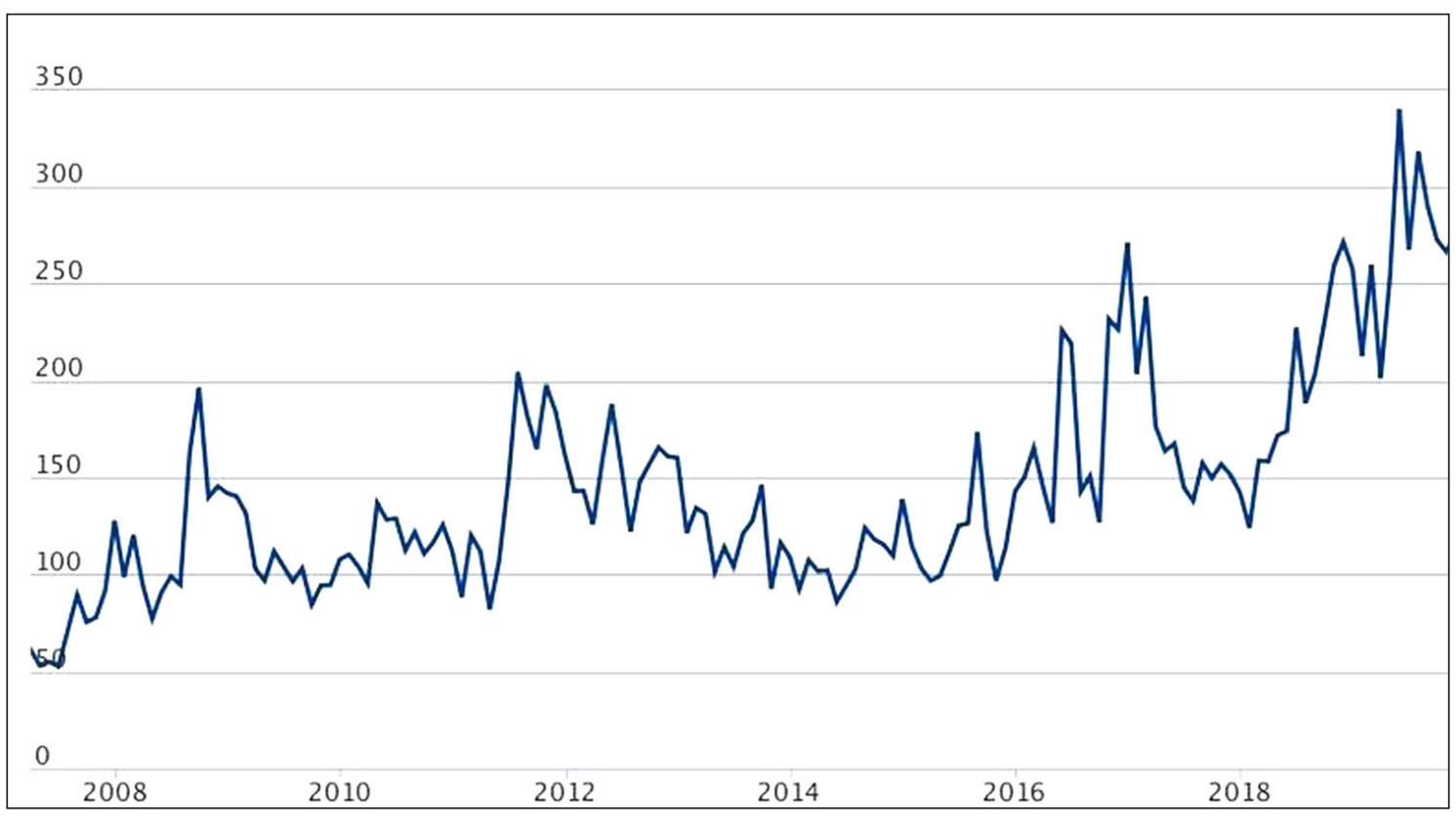

Sumber: https://www.policyuncertainty.com/

Grafik 1 menunjukkan indeks ketidakpastian dunia dari tahun 2007 hingga 2019. Indeks ini dikembangkan oleh Ahir et al. (2018), dengan menggunakan laporan Economist Intelligence Unit (EIU) yang dilaporkan oleh setiap negara. Pada laporan tersebut, Ahir et al. (2018) menghitung jumlah kata "uncertain", "uncertainty", and "uncertainties" pada topik ekonomi dan perkembangan politik untuk laporan EIU setiap negara. Pada penelitiannya, Ahir et al. (2018) menghasilkan ukuran ketidakpastian untuk 143 negara berkembang dan maju, sekaligus ukuran ketidakpastian pada level dunia (world uncertainty index (WUI)). Pada grafik 1 dapat terlihat indeks WUI dari tahun 2007-2019. Seperti yang dapat kita lihat pada grafik 1 bahwa terjadi peningkatan ketidakpastian pada periode krisis keuangan global (tahun 2008-2009), great recession in Europe (tahun 2011-2012), dan perang dagang China-US (period 2018-2019).

Grafik 1 juga menunjukan bahwa tren dari tingkat ketidakpastian dunia terus meningkat dari tahun ke tahun. Hal ini menjadi latar belakang dari penilitian ini untuk melihat efek ketidakpastian bagi perusahaan. Informasi menjadi faktor penting dalam melakukan perencanaan. Maka menjadi menarik bagi peneliti untuk melihat perilaku perusahaan terhadap ketidakpastian yang dialaminya. Sesuai dengan argumen-argumen tersebut, penelitian ini bertujuan untuk menguji hipotesis bahwa ketidakpastian dapat mengurangi tingkat utang perusahaan. Penelitian ini berkontribusi pada literatur dengan memberikan bukti pada efek ketidakpastian pada kebijakan utang perusahaan di Indonesia. Penelitian mengenai ketidakpastian kebanyakan dilakukan pada negara maju, sehingga penelitian ini dapat berkontribusi pada pembuktian di negara berkembang. Dengan menggunakan data ketidakpastian yang dikembangkan oleh Ahir et al. (2018), studi ini menemukan bahwa ketidakpastian menyebabkan penurunan pada tingkat utang perusahaan. Ketidakpastian menyebabkan biaya utang menjadi mahal dan risiko gagal bayar perusahaan, sehingga perusahaan memilih untuk mengurangi tingkat utangnya. 


\section{METODE}

Penelitian ini menggunakan sampel perusahaan Indonesia yang terdaftar pada Bursa Efek Indonesia (BEI). Perusahaan pada industri keuangan dan perbankan dikeluarkan dari sampel, dikarenakan perusahaan-perusahaan tersebut memiliki peraturan dan struktur modal yang cukup berbeda dibandingkan dengan perusahaan pada industri lain. Selain itu, observasi yang tidak memiliki data penelitian yang dibutuhkan juga akan dieliminasi dari observasi penelitian. Penelitian ini menggunakan data laporan keuangan kuartal pada periode 2007 kuartal 1 hingga 2019 kuartal 4. Data set laporan keuangan diperoleh dari S\&P capital IQ. Peneliti menggunakan unbalanced panel data, di mana setiap perusahaan memiliki jumlah data time series yang berbeda. Sehingga, total keseluruhan observasi yang digunakan adalah sebesar 17,849 observasi perusahaan-kuartal. Data ketidakpastian yang dikembangkan oleh Ahir et al. (2018) diperoleh langsung dari situs (https://www. policyuncertainty.com/).

Metode analisis penelitian ini menggunakan metode regresi panel data. Variabel ketidakpastian $(U n c)$ digunakan data $\mathrm{t}-1$, hal ini dikarenakan keputusan utang perusahaan tidak langsung beraksi (contemporaneous effect) melainkan membutuhkan waktu penyesuaian satu kuartal (Pan et al., 2019). Berikut adalah model empiris penelitian yang digunakan untuk menguji hipotesis:

$$
\operatorname{Lev}_{i, t}=\alpha+\beta_{1} \text { Unc }_{t-1}+\beta_{2} \text { Cash }_{i, t}+\beta_{3} R_{0 A} A_{i, t}+\beta_{4} M B_{i, t}+\beta_{5} \text { Invest }_{i, t}+\beta_{6} S Z_{i, t}+\varepsilon
$$

Keterangan:

Lev : Tingkat utang perusahaan

Unc : Ketidakpastiaan (world uncertainty index (WUI) dan ketidakpastian Indonesia)

Cash : Uang kas yang dipegang perusahaan

ROA : Profitabilitas perusahaan

$M B \quad$ : Investment opportunity

Invest : Tingkat investasi perusahaan

SZ : Ukuran perusahaan

Berikut adalah operasionalisasi dari variabel yang digunakan pada penelitian ini:

1. Leverage (Lev)

Variabel ini digunakan utnuk mengukur tingkat utang yang digunakan oleh perusahaan. Semakin tinggi nilai dari tingkat leverage yang dimiliki perusahaan menunjukan jumlah utang yang digunakan perusahaan juga tinggi.

$$
\text { Lev }=\frac{\text { Total Liabilitas }}{\text { Total Aset }}
$$

2. Ketidakpastian $(U n c)$

Untuk mengukur ketidakpastian, penelitian ini menggunakan ukuran ketidakpastian yang dikembangkan oleh Ahir et al. (2018) yang diperoleh langsung dari situs (https://www. policyuncertainty.com/). Ukuran ketidakpastian yang digunakan adalah ketidakpastian pada level dunia (world uncertainty index (WUI)) dan pada level Indonesia. 
3. $\quad$ Cash holding (Cash)

Varibel cash holding adalah jumlah uang kas yang dipegang oleh perusahaan.

$$
\text { Cash }=\frac{\text { Cash \& Cash Equivalents }}{\text { Total Aset }}
$$

4. Profitabilitas (ROA)

Untuk mengukur profitabilitas, penelitian ini menggunakan ukuran tingkat pengembalian atas total aset yang diinvestasikan (ROA) dengan rumus sebagai berikut.

$$
R O A=\frac{\text { Net Income }}{\text { Total Aset }}
$$

5. Investment opportunity (MB)

Pendanaan eksternal digunakan oleh perusahaan untuk membiayai kesempatan investasi yang dimiliki perusahaan. Ukuran dari investment opportunity yang digunakan adalah dengan rasio nilai ekuitas pasar pada nilai ekuitas buku.

$$
M B=\frac{\text { Market Capitalization }}{\text { Book value of Equity }}
$$

6. $\quad$ Investment (Invest)

Model penelitian ini juga menggunakan tingkat investasi perusahaan sebagai variabel independen.

7. $\quad$ Size (SZ)

Ukuran perusahaan (Size) yang digunakan pada penelitian ini adalah dengan menggunakan logaritma natural dari total aset perusahaaan.

$$
S Z=\ln (\text { Total Aset })
$$

\section{HASIL DAN PEMBAHASAN}

\section{Analisis statistik deskriptif}

Pada tabel 1 disajikan deskripsi statistik dari seluruh variabel yang digunakan pada model empiris penelitian ini. Untuk mengetasi masalah outlier, variabel yang digunakan dilakukan proses winsorization pada persentase 1\%. Pada tabel 1 dapat terlihat bahwa total keseluruhan observasi yang digunakan pada penelitian ini adalah sebesar 17,849 observasi. Variabel WUI adalah world uncertainty index yang merupakan ukuran ketidakpastian secara global. Variabel ini diukur dengan logaritma natural dari data world uncertainty index. Sedangkan untuk ukuran ketidakpastian pada level negara Indonesia (INDOUNC) adalah ketidakpastian yang telah dinormalisasi oleh Ahir et al. (2018). Semakin tinggi nilai WUI dan INDOUNC menunjukkan tingginya ketidakpastian pada level dunia dan Indonesia. 
Tabel 1. Statistik Deskriptif

\begin{tabular}{cccccc}
\hline Variabel & Obs & Mean & Std. Dev. & Min & Max \\
\hline WUI & 17849 & 9.961 & .38 & 9.016 & 10.873 \\
INDOUNC & 17849 & .138 & .147 & 0 & .877 \\
LEV & 17849 & .514 & .323 & .038 & 2.393 \\
CASH & 17849 & .102 & .113 & .001 & .576 \\
ROA & 17849 & .018 & .027 & -.057 & .126 \\
MB & 17849 & 1.625 & 1.655 & .294 & 11.899 \\
INVEST & 17849 & .013 & .021 & -.023 & .116 \\
SZ & 17849 & 28.317 & 1.69 & 24.385 & 32.237 \\
\hline
\end{tabular}

Sumber: Data sekunder yang diolah.

Variabel lainnya seperti $L E V, C A S H, R O A, M B$, INVEST, dan SZ memiliki data yang wajar terlihat pada statistik rata-rata (mean), standar deviasi, nilai minimum dan maksimum yang ditampilkan pada tabel 1. Hal ini membuat peneliti memutuskan untuk melanjutkan analisis model regresi dengan menggunakan data-data tersebut.

\section{Pengujian Hipotesis}

Untuk mengatasi masalah heteroskedastisitas, autokorelasi dan cross dependence, regresi penelitian ini mengaplikasikan driscoll-kraay standard errors (Hoechle, 2007). Pada tabel 2 ditampilkan hasil regresi panel data driscoll-kraay standard errors untuk melakukan analisis uji hipotesis penelitian ini. Seperti yang disajikan pada tabel 2, bahwa nilai F statistik pada kolom 1 dan 2 menunjukan bahwa model yang digunakan adalah valid sehingga dapat digunakan untuk mengambil kesimpulan atas hipotesis yang diuji.

Pada tabel 2 kolom 1, koefisien dari variabel INDOUNC menunjukan tanda negatif signifikan pada level $10 \%$. Hal ini menunjukkan bahwa ketidakpastian yang berada pada level negara mengurangi utang perusahaan. Selanjutnya, koefisien WUI yang juga negatif signifikan menujukkan bahwa ketidakpastian pada level global menyebabkan penurunan utang pada perusahaan. Kedua hasil ini sesuai dengan hipotesis penelitian ini, yaitu bahwa utang perusahaan cenderung lebih rendah pada periode dengan tingkat ketidakpastian yang tinggi. Hasil ini menjadi bukti bahwa ketidakpastian meningkatkan informasi asimetris antara kreditor dan perusahaan sehingga menyebabkan biaya utang menjadi mahal. 
Tabel 2 Hasil Regresi Panel Data

\begin{tabular}{|c|c|c|}
\hline & (1) $L E V$ & (2) $L E V$ \\
\hline \multirow[t]{2}{*}{$\operatorname{INDOUNC}_{t-1}$} & $-.012^{*}$ & \\
\hline & $(.009)$ & \\
\hline \multirow[t]{2}{*}{$W U_{t-1}$} & & $-.016^{* *}$ \\
\hline & & $(.006)$ \\
\hline \multirow[t]{2}{*}{ Cash $_{i, t}$} & $-.348^{* * *}$ & $-.347^{* * *}$ \\
\hline & $(.037)$ & $(.037)$ \\
\hline \multirow[t]{2}{*}{$R O A_{i, t}$} & $-.884^{* * *}$ & $-.898^{* * *}$ \\
\hline & $(.139)$ & $(.14)$ \\
\hline \multirow[t]{2}{*}{$M B_{i, t}$} & $.031^{* * *}$ & $.031^{* * *}$ \\
\hline & $(.005)$ & $(.005)$ \\
\hline \multirow[t]{2}{*}{ Invest $_{i, t}$} & $-.267^{* * *}$ & $-.282^{* * *}$ \\
\hline & $(.089)$ & $(.089)$ \\
\hline \multirow[t]{2}{*}{$S Z_{i, t}$} & $-.013^{* * *}$ & $-.01^{* *}$ \\
\hline & $(.003)$ & $(.004)$ \\
\hline \multirow[t]{2}{*}{ _cons } & $.887^{* * *}$ & $.953^{* * *}$ \\
\hline & $(.09)$ & $(.07)$ \\
\hline Observations & 17230 & 17230 \\
\hline No. Firms & 479 & 479 \\
\hline F test & 31.73 & 55.58 \\
\hline $\mathrm{R}^{2}$ & 0.0664 & 0.0674 \\
\hline \multicolumn{3}{|c|}{ Standar error didalam kurung } \\
\hline \multicolumn{3}{|l|}{$* * * \mathrm{p}<.01, * * \mathrm{p}<.05, * \mathrm{p}<.1$} \\
\hline
\end{tabular}

Sumber: Data sekunder yang diolah.

Ketidakpastian menyebabkan arus kas perusahaan menjadi berfluktuasi, sehingga kreditor meminta tingkat imbal hasil yang lebih tinggi atas risiko yang ditanggungnya (Xu, 2020). Tingginya biaya utang menurunkan keinginan perusahaan untuk berutang (Pan et al., 2019; Waisman et al., 2015; Xu, 2020) dan dapat berakibat pada penundaan investasi perusahaan (Bloom et al., 2007; Gulen dan Ion, 2016). Hal ini perlu menjadi perhatian bagi policy maker seperti pemerintah, Bank Indonesia maupun Otoritas Jasa Keuangan (OJK) untuk dapat mengambil kebijakan yang meningkatkan gairah investasi perusahaan ketika terjadi ketidakpastian yang tinggi. Misalnya seperti peningkatan pada financial development suatu negara akan dapat menurunkan masalah friksi keuangan yang dihadapi oleh perusahaan (Levine, 2005). Tanpa adanya pendanaan yang memadai dapat mengakibatkan perusahaan untuk kesulitan dalam mengambil investment opportunity (positive NPV project) yang dimilikinya. Hal ini penting karena investasi merupakan salah 
satu faktor utama yang dapat mempengaruhi peningkatan pertumbuhan ekonomi suatu negara.

Hal lain yang menarik dari hasil penelitian yang ditunjukkan pada tabel 2 adalah perbandingan antara ketidakpastian level dunia (WUI) dan Indonesia (INDOUNC). Jika dilihat dari nilai koefisiennya, WUI memiliki koefisien yang lebih tinggi dibandingkan dengan INDOUNC. Hasil ini menunjukkan bahwa ketidakpastian dunia memiliki pengaruh yang lebih tinggi pada keputusan utang perusahaan. Dengan kata lain, perusahaan di Indonesia lebih sensitif terhadap ketidakpastian dunia dibandingkan dengan ketidakpastian yang ada di Indonesia. Pada era digitalisasi memudahkan untuk informasi berpindah antar negara dengan sangat cepat, sehingga memungkinkan informasi dari manapun untuk dapat mempengaruhi keputusan yang diambil.

Variabel kontrol pada penelitian ini memiliki pengaruh yang konsisten sesuai dengan penelitian terdahulu. Perusahaan dengan kas $(\mathrm{CASH})$, profitabilitas (ROA) dan ukuran (SZ) yang besar cenderung lebih tidak menggunakan utang dikarenakan mereka memilih untuk menggunakan sumber pendanaan internal yang lebih murah. Sedangkan untuk perusahaan dengan kesempatan investasi $(M B)$ yang tinggi memilih untuk mengambil pendanaan eksternal untuk dapat mencukupi modal yang dibutuhkan untuk mengambil kesempatan berinvestasi.

\section{SIMPULAN}

Penelitian ini bertujuan untuk memberikan kontribusi pada literatur dengan menemukan bukti empiris pada pengaruh ketidakpastian pada keputusan pendanaan yang diambil oleh perusahaan. Hasil yang didapatkan dari penelitian ini menunjukkan bahwa ketidakpastian pada tingkat negara dan dunia mengurangi tingkat utang perusahaan. Hal ini sesuai dengan penelitian terdahulu yang menemukan bahwa tingginya ketidakpastian pada ekonomi menyebabkan para pelaku pada pasar modal menjadi takut untuk berinvestasi dan meminjamkan uangnya kepada perusahaan. Terbatasnya ketersediaan pendanaan meningkatkan friksi keuangan dan mengakibatkan biaya pendanaan menjadi lebih mahal. Ditambah lagi, perusahaan menjadi khawatir dengan mahalnya biaya utang yang dikenakan dapat meningkatkan ketidakmampuan mereka untuk dapat membayarkan kewajibannya. Pada akhirnya, perusahaan memutuskan untuk mengurangi utang guna membiayai kesempatan investasi perusahaan.

Pengambil kebijakan (policy maker) perlu menyadari bahwa ketidakpastian memberikan pengaruh pada keputusan pendanaan yang diambil perusahaan. Seperti yang kita ketahui bahwa pendanaan menjadi salah satu faktor utama dalam pengambilan keputusan investasi perusahaan. Mahalnya biaya utang dapat menyebabkan perusahaan kesulitan mendanai investasinya. Sehingga, pengambil kebijakan perlu mengambil kebijakan-kebijakan yang dapat meningkatkan akses perusahaan untuk mendanai investasinya. Penemuan lainnya yaitu bahwa perusahaan di Indonesia lebih sensitif terhadap ketidakpastian dunia dibandingkan dengan ketidakpastian di Indonesia. Hasil ini menarik untuk menjadi perhatian peneliti selanjutnya untuk dapat membahas bagaimana perusahaan Indonesia memiliki sensitivitas 
yang lebih tinggi pada ketidakpastian dunia dibandingkan dengan ketidakpastian pada level negara.

\section{PUSTAKA ACUAN}

Ahir, H., Bloom, N., \& Furceri, D. (2018). The World Uncertainty Index. SSRN Electronic Journal.

Baker, S. R., Bloom, N., \& Davis, S. J. (2016). Measuring Economic Policy Uncertainty. The Quarterly Journal of Economics, 131(4), 1593-1636.

Bloom, N., Bond, S., \& Van Reenen, J. (2007). Uncertainty and investment dynamics. Review of Economic Studies, 74(2), 391-415.

Cao, W., Duan, X., \& Uysal, V. B. (2017). Does Political Uncertainty Affect Capital Structure Choices? Journal of Chemical Information and Modeling.

Francis, B. B., Hasan, I., \& Zhu, Y. (2014). Political uncertainty and bank loan contracting. Journal of Empirical Finance.

Gulen, H., \& Ion, M. (2016). Policy uncertainty and corporate investment. Review of Financial Studies.

Hoechle, D. (2007). Robust standard errors for panel regressions with cross-sectional dependence. Stata Journal.

Lee, D. H., Min, B. K., \& Kim, T. S. (2019). Dispersion of beliefs, ambiguity, and the crosssection of stock returns. Journal of Empirical Finance, 50, 43-56.

Levine, R. (2005). Chapter 12 Finance and Growth: Theory and Evidence. Handbook of Economic Growth.

Pan, W. F., Wang, X., \& Yang, S. (2019). Debt maturity, leverage, and political uncertainty. North American Journal of Economics and Finance.

Pástor, L'., \& Veronesi, P. (2013). Political uncertainty and risk premia. Journal of Financial Economics.

Phan, H. V., Nguyen, N. H., Nguyen, H. T., \& Hegde, S. (2019). Policy uncertainty and firm cash holdings. Journal of Business Research, 95(September 2018), 71-82.

Stokey, N. L. (2016). Wait-and-see: Investment options under policy uncertainty. Review of Economic Dynamics, 21, 246-265.

Waisman, M., Ye, P., \& Zhu, Y. (2015). The effect of political uncertainty on the cost of corporate debt. Journal of Financial Stability, 16, 106-117.

$\mathrm{Xu}, \mathrm{Z}$. (2020). Economic policy uncertainty, cost of capital, and corporate innovation. Journal of Banking and Finance, 111. 